\title{
Special Issue on the Group for New Directions in Pastoral Theology: In Memory of Donald Capps (1939-2015), Part One
}

\author{
Nathan Carlin $^{1} \cdot$ Robert C. Dykstra ${ }^{2}$
}

Published online: 13 July 2016

(C) Springer Science+Business Media New York 2016

We are grateful once again to Lewis Rambo for allotting such significant space (two consecutive issues) in this journal to publish papers presented during two meetings of the Group for New Directions in Pastoral Theology. These meetings took place at Princeton Theological Seminary, in Princeton, New Jersey, from May 6-8, 2015, and from October 14-16, 2015. The theme for the May meeting was "New Directions with Children and Adolescents." The theme for the October meeting was "Creativity, Imagination, and Method in Pastoral Theology." Papers from previous conferences have been published as articles in Pastoral Psychology in the December 2010, June 2011, August 2012, October 2013, December 2014, and October 2015 issues.

It is with real sadness but also great thanksgiving that we offer these papers in memory of Donald Capps, who died, at age 76, on August 26, 2015, from injuries sustained in an automobile accident that occurred just a few hundred feet from the conference center in which the Group for New Directions regularly meets. Participants' grief at the death of Professor Capps, a co-founder of the Group who had attended every meeting since its inception, was heartfelt at its October 2015 meeting. There we shared memories, shed tears, and expressed our deep affection for a friend, mentor, and brilliant colleague who embodied creativity and dedication to the discipline of pastoral theology. Capps's work ethic was unsurpassed, and he became the most prolific writer in the history of the field. He accomplished this, however, without self-promotion or taking himself too seriously. He lightened every gathering with humor, typically helping his students and friends to reframe their struggles in order to discover more hopeful possible ends.

Robert C. Dykstra

robert.dykstra@ptsem.edu

Nathan Carlin

Nathan.Carlin@uth.tmc.edu

1 McGovern Center for Humanities and Ethics, McGovern Medical School, 6431 Fannin Street, JJL 410, Houston, TX 77030, USA

2 Princeton Theological Seminary, P.O. Box 821, Princeton, NJ 08542-0803, USA 
Part One of this special issue begins with a memorial tribute to Professor Capps by Robert Dykstra and Nathan Carlin. It concludes with a bibliography of his publications from 2009 to the present. A bibliography encompassing his publications from 1968 to 2009 was previously published in the December 2009 issue of this journal (see Dykstra \& Cole, 2009).

At the end of each meeting of the Group for New Directions in Pastoral Theology, participants devote an hour to considering possible themes for the next gathering. We noticed at our May 2014 meeting that a number of papers referred, directly or indirectly, to pastoral work with children or adolescents. At the same meeting, participants reaffirmed the view that pastoral theology tends to be story-oriented. The conference organizers thought that this emphasis on story would meld nicely with a focus on children and adolescents.

Thus, for the May 2015 meeting, participants were invited to write on stories about an individual child or adolescent, or on children in families, congregations, or local communities, while likewise considering how these stories intersect with racial, ethnic, or gender concerns. The conference invitation also noted that inclusion in conference papers of stories about an individual child or young person from a biblical narrative, from one of Jesus's parables, or from contemporary life, as well as studies on children and adolescents from psychology or other social sciences, would all be in keeping with past emphases of the Group.

The theme for the October 2015 meeting was similarly derived from an earlier meeting in October 2014. Here participants were encouraged to write a paper on method in pastoral theology, and to do this not so much by engaging the writings of their predecessors or teachers but instead by reflecting on the nature of their own work. More will be said about the development of this latter theme in the preface to the December 2016 issue, which will center on papers from the October 2015 meeting. Articles from either of these conference gatherings that appear in the present issue tend to engage Professor Capps's life and work somewhat more directly, and we therefore seek to link them here with our memorial tribute to him. But we offer both issues in memory of Donald Capps, whose influence in pastoral theology and the psychology of religion is cherished by us and by many colleagues and friends around the nation and the globe.

\section{References}

Dykstra, R., \& Cole, A. (2009). Books and articles by Donald Capps. Pastoral Psychology, 58(5-6), 681-693. 